\title{
Personalization and learning: innovative approaches to teaching for e-learning
}

\author{
Personalization and learning
}

\author{
Ray Webster \\ Fay Sudweeks
}

\begin{abstract}
This paper suggests that for academics to be good teachers, especially in the context of e-Learning, they need to understand learning. This is especially important with the associated changes in higher education as we move towards the knowledge society. E-Learning is embedded in learning and, without an understanding of what learning encompasses, it can be difficult for academics to develop into good teachers. It is suggested that, although this may appear to be a simple aim, it is not necessarily understood or applied by university academics in their teaching. One inference is that university teachers need to develop a theory of learning and teaching. Academics may have a 'philosophy of teaching', but in many cases even this may not be consciously held or successfully implemented. A program for promoting conceptual change in academics' approaches to teaching is outlined.

Keywords: Learning; Knowledge; Technology
\end{abstract}

\section{Personalização e aprendizado: novos métodos para ensinar em e-learning}

\section{Resumo}

Esse artigo sugere que para estudantes serem bons professores, especialmente no contexto do e-Learning, é necessário entender de aprendizagem. Isso é especialmente importante devido às mudanças na educação superior, na medida em que nos movemos em direção a uma sociedade de conhecimentos. O e-Learning é baseado em aprendizagem e tem objetivo de formar bons professores, porém sua compreensão pode ser difícil para acadêmicos que não compreendem quais aspectos a aprendizagem engloba. Apesar de seu objetivo ser simples, ele não é necessariamente compreendido ou aplicado por acadêmicos universitários no ensino. Um dos problemas é que professores universitários têm que desenvolver uma teoria de aprendizagem e ensino. Logo, acadêmicos podem ter uma filosofia de ensino mas, em muitos casos, até essa filosofia pode não ser conscientemente realizada ou implementada com sucesso. Um programa para promover mudanças conceituais nas técnicas de ensino dos estudantes é destacado no artigo.

Palavras-chave: Aprendizagem; Conhecimento; Tecnologia.

\section{Personalización y aprendizaje: nuevos métodos para enseñar en e-learning}

\section{Resumen}

Este artículo sugiere que para que estudiantes sean buenos profesores, especialmente en el contexto e-learning, es necesario entender sobre aprendizaje. Eso es especialmente importante por causa de los cambios en la educación superior, en la medida en que nos movemos en dirección a una sociedad de conocimientos. El e-learning es basado en aprendizaje y tiene como objetivo formar buenos profesores, pese a que su comprensión puede ser difícil para los académicos que no entienden cuales aspectos son englobados por el aprendizaje. Pese a su objetivo ser simple, no necesariamente es entendido o aplicado por universitarios académicos en la enseñanza. Uno de los problemas es que los profesores universitarios tienen que desarrollar una teoría de aprendizaje y enseñanza. De esa forma, los académicos pueden tener una filosofía de enseñanza, pero en muchos casos, esa propia filosofía puede no ser conscientemente realizada o implementada con suceso. Un programa para promover cambios conceptuales en las técnicas de enseñanza de los estudiantes es destacado en el artículo.

Palabras clave: Aprendizaje; Conocimiento; Tecnología. 


\section{Introduction}

Good practice in learning and teaching requires an understanding of learning. This is true for e-Learning as the purpose of the technologies and associated processes is still to support learning itself. An understanding of learning is best accessed through an individual's understanding of his/her own learning followed by an appreciation of the large variations in approaches to learning existing in and adopted by any given body of students. This paper suggests a strategy and methodology for enabling conceptual change in academics' approaches to teaching for learning in the knowledge society by engaging with these issues.

The mechanism for operationally these matters is provided by the concept of student learning profiles. Each individual has a learning profile, the core constituents of each profile are cognitive style, learning style and personality type. These three profile components interact in ways which produce very individual and personalised approaches to learning. Facilitating an understanding of the range of possible learner profiles via accessing and reflecting on their own profile can help enable academics to become more effective teachers amidst the increasing demands of higher education as we move towards a more fullfledged knowledge society. These issues will be explored using data from a study of four hundred students and a team of tutors and teachers participating in a foundation level unit, "Learning at University".

\section{Purpose and rationale of the research}

The overall purpose of the research is to provide a strategy for developing a network of disciplinary leaders for excellence in learning and teaching in information technology. This will be achieved by enabling conceptual changes in the approaches of academics to their teaching and will be operationalised by using an understanding of personal learning to enhance the teaching skills of university teachers.

Working from a subject dependent (information technology) and departmental base, the intention is to provide a framework which can be extended in two ways. The first is from the departmental level through the faculty level to the institutional level. The second is by providing a subject independent methodology that can be adapted to each area.

The rationale for the project is that, for academics to be good teachers, they need to understand learning. The purpose of teaching is to enable learning. Without an understanding of what learning encompasses, it can be difficult for many academics to develop into good teachers. A much quoted phrase from Paul Ramsden (1992) emphasises this view: "The aim of teaching is simple: it is to make student learning possible" (p. 5). While it might be quoted often and proclaimed to be a simple aim, that aim is not necessarily understood (and especially applied) by university academics in their teaching. The following quote highlights this proposition. An inference is that university teachers need to develop a theory of learning and teaching.

"[l]t is difficult to find an academic with a theory of learning. Or even one who thinks it is his job to have one" (Laurillard, 1999, p. II3).

Most academics may well have a 'philosophy of teaching' rather than a 'theory of learning', possibly linked to their own experiences as students and most likely related to their personal preferences for presenting and receiving information. However, in many cases, even this may not be consciously held or successfully implemented.

Good practice in learning and teaching requires an understanding of learning. This understanding of learning is best accessed through an individual's understanding of his/her own learning followed by an appreciation of the large variations in approaches to learning existing in and adopted by any given body of students. This project proposes the use of 'leaders for excellence in learning and teaching'. These leaders will be individuals who understand, use, champion and spread the use of learning profiles as a method of understanding learning to enhance teaching.

The mechanism for operationalising these issues is provided by the concept of a Learning Profile (LP). Each individual has a Learning Profile (Webster, 
2005) and we can identify three core constituents of each profile: (i) cognitive style, (ii) learning style, and (iii) personality type. This is in line with Jonassen and Grabowski (1993) who, in a broad survey of individual learning, commented that "the particular combination of aptitudes and traits possessed by each individual is reflected in the individual's cognitive styles, personality, and learning styles" ( $p$. $x i)$. These attributes, then, comprise the main elements of the learning profile. These three profile components interact in ways which produce very individual and personalised approaches to learning. Enabling and enhancing metacognition by both university teachers and students can be achieved by the process of self-reflection on learner characteristics or profiles. Learner characteristics and the related interactions with others can have a large impact on the individual learning process and, by definition, the teaching process. How individual university teachers approach their teaching and develop their teaching strategies is strongly related to their own individual learning profiles. As groups and learning communities are aggregations of individual learners, it follows that these characteristics also impact on all aspects of teaching and learning including individual learning, group learning and, ultimately, learning community development.

That academics are increasingly expected to have a 'theory of learning' is representative not only of a shift in focus in higher education, but of a series of changes throughout the sector which can be described as producing a major systems reconfiguration (Ison, 1999, 2000). Within this context, and from a systems perspective, understanding how students learn can be considered to be central to designing environments to support student learning - whether those environments be social (e.g. learning support groups), technical (Blackboard, WebCT, etc.) or organisational (e.g. the department, faculty or university as learning environment). From the academics' perspective, this is simply one more change factor that they have to take into consideration amidst increasing student numbers, falling resource levels and changing systems.

\section{Helping University Teachers to Develop a 'Theory of Learning'}

While it is easy to bemoan the possible shortcomings of university teachers in this area, the quote from Laurillard suggests that the need to adopt a 'theory of learning' is unlikely to be apparent to many. Consequently, a more difficult task is that of helping university teachers to develop a 'theory of learning' that is accessible and makes sense to each and every one. The methodology proposed in this project will enable such a theory to be developed in a constructive and applicable manner. This will be done by personalising the learning process while at the same time locating it in the context of the huge range of possible individual learning profiles.

This initial project is centred on Information Technology departments; however, the project can be extended to different student constituencies. The major aims of the project are to:

- implement a strategy of developing a network of disciplinary leaders for excellence in learning and teaching in information technology;

- provide an action research model which will attract participants, directly impact on their professional effectiveness, and increase involvement;

- enable university teachers to understand their own learning via personal learning profiles and extend this understanding to the range of possible learning profiles, the consequent approaches to learning and the implications for effective teaching;

- create a professional development strategy for moving the action research model from a departmental to a faculty approach and thence to a university wide approach; and

- create a professional development strategy for moving the action research model from an information technology subject base to other subjects.

\section{Approach and Methodology}

The research aims fit in with general institutional priorities in higher education. All universities are committed to enhancing student learning through the 
development of teaching excellence. The following are extracts from strategy documents of example Australian universities:

- Murdoch University, WA: To enhance the educational quality of courses and the teaching and learning experience ... To maintain student satisfaction with the quality of teaching within the top $20 \%$ of the Australian public universities.

- University of Technology, Sydney (UTS), NSW: Use research on learning and feedback on teaching to identify good practice and inform UTS teaching standards ... Develop communities of UTS teaching practice that increase the exchange of ideas and the dissemination of good practice.

- Edith Cowan University (ECU), WA: Enhancing Teaching, Learning and Research: ECU will become a national leader in the education of learners for the knowledge based service professions, and will be recognised for the quality of its teaching and its learning opportunities in those fields ... ECU is a teaching and research university, and research will inform its teaching especially research into the scholarship of teaching and learning.

The major outcomes proposed are as follows.

- A network of disciplinary leaders for excellence in learning and teaching in information technology at each institution will be created.

- A strategy for enabling teaching via conceptual change in university teachers understanding of learning will be developed and implemented.

- A flexible approach (the learning profile measures can be varied) which can be adapted for different subject areas (via changes in the unit activities) will be introduced.

- An aligned and integrated institutional/faculty/ departmental approach will be provided.

- A professional development strategy for moving the action research model from a departmental to a faculty approach and thence to a university wide approach will be formalised.
- A professional development strategy for moving the action research model from an information technology subject base to other subjects will be formalised.

- A series of workshops and materials to enable the dissemination of the program and strategies will be organised.

Additional outcomes for academics participating in the iterative process of reflection on learning profiles and their application via teaching include the following.

- A deeper understanding of the learning process, as applied to the teacher and the student, is developed by each academic.

- A deeper understanding of the range of learning profiles possible in any given student body is developed by each academic.

- The ability to adapt one's teaching for whole group learning is developed.

- A framework is provided that affords both a structure to work within and a process to follow.

- Participation in the process will help university teachers and students to develop metacognitive skills and explore their attitudes to learning in a manner which will promote Life Long Learning.

\section{Conceptual Framework}

The conceptual framework for the research draws on current international developments in personalised learning (DfES, 2004; Martinez, 200I; Metros \& Bennett, 2002) and the recognition that these developments have their roots in "the best practices of the teaching profession" (DfES, 2004). It also builds on research on the reflective practitioner (Schön, 1983, 1991) and learning organisations (Argyris \& Schön, 1996), and the Soft Systems Methodology implementation of this (Checkland \& Scholes, 1990). Within this context, the concept of learning profiles (Webster, 2004), derived from available psychometric measures, is used to provide a framework for reflection. A process of individual reflection and peer group discussion is used as the basis for the design and development of a Personalised Teaching Resource 
Portal (PTRP). By using the teacher's understanding of the learning process via self-knowledge, the core of the work is the fundamental link between learning, reflection and good teaching practice.

In order to the learning profile derivation, three instruments have been selected based on empirical evidence of their validity and reliability as measurements and constructs. As with many psychometric measures, there is continued debate about the use of each (Geyer, 1997; Peterson et al, 2003). However, they are used as indicators of the range of styles and characteristics available in each element of the profile and indicate the self reported strengths of learning preferences rather than acting purely as quantitative measures in a quasi-experimental mode. As such they are reflective tools which the participants use as a framework to locate and consider the factors underpinning their own approaches to learning and teaching.

The three components of the Learning Profile and the instruments used to measure them are:

- Cognitive Style - the Cognitive Styles Analysis (Riding, 199I, 2000) is a I5 minute computerbased test which measures personal preferences for representing and processing information.

- Learning Style - the Approaches to Study Inventory (Entwistle et al, 200I; Tait et al., 1998) aims to measure deep, surface and strategic approaches to learning in addition to other categories of learning.

- Personality Type - the Myers-Briggs Type Inventory (Myers et al., 1998) is an educational and management tool which classifies respondents according to personality type and is strongly related to measures of cognitive and learning styles.

Considering the application, the core methodology is provided by RAPAD (a Reflective and Participatory Approach to Design) (Webster, 2005). RAPAD is a developmental methodology which encourages reflection within the context of a participatory approach to design.
Elements of the conceptual framework include:

I. the development and application of the cognitive profile concept to provide a structured and accessible summary of teachers' learning characteristics;

2. the use of the profiles as a framework for structured reflection on learning characteristics;

3. the identification of the impact of learner characteristics, as derived from the cognitive profiles, on the dynamics of group learning;

4. the identification of key profiles for the development of successful learning groups and communities; and

5. the development of a methodology for enhancing teachers' metacognitive awareness of group learning with reference to the formation of learning communities.

In this case, the developmental methodology encourages reflection by university teachers on aspects of their own learning and participation in the process of the design and development of personalised portals. The development of the portal is a major part of the reflective and reflexive development as it requires the individual to fully engage with his or her profile in the act of applying it within the context of a design application.

The overall process for each academic begins with critically reflecting on the elements of a personal learning profile. This is first done individually and then within the context of the project team, both within and across the three universities using a learning management site designed for the purpose. The comparative group discussions help the development of an understanding of the broader range of possible learning profiles. The results of the reflections, discussions and emerging design plans will then be applied to the design and development of a PTRP by each participating academic.

The methodology uses multiple data sources and mixed data types (Webster, 2004). The data sources include pre- and post-questionnaires, reflective journals, interviews and structured design 
commentary (i.e. a walk through of the form and content of the PTRP where the participant explains the relationship and purpose of each element in the context of his or her learning profile). Using this methodology in the context of this research project also enables a conceptual change in the participating university teachers' approaches to teaching via an understanding of the learning process.

\section{Methodological Process and Stages}

\section{Institutional Teaching Team Focus}

Stage I: The project leaders at each university will be familiar with the concepts and practices of learner profiling. They will have undertaken the series of reflective and practical activities involved in the process. Each project team member will take responsibility for a group of participating staff and each institutional leader will recruit four academics who wish to participate in the research.

Stages 2: Participating staff (ratio of I leader to 4 participants) will undertake the same process of profiling, reflection and comment, guided by the institutional leaders. At the outset, each participant will first have been asked to sketch an outline of what his/her learning profile might be. This will be done for comparative purposes and with reference to the learning profile elements, e.g. cognitive style - field dependent/independent, holist/analytic, verbaliser/ visualiser; personality type - according to MBTI type; learning style profile - deep, surface or strategic learning style propensity.

Stage 3: The participants will develop a relatively straightforward web-based teaching and learning support portal. The PTRP will have teaching and learning support processes and objects embedded in the structure which are based on the learning profile of the individual developer. This will allow the participants to apply their learning in a practical context and will serve to strengthen their understanding of how the elements of their learning profile impact on various aspects of the learning process - and by means of that, the related and interconnected teaching process. The knowledge management and portal design consultant will play an important part throughout this period, being available for consultation and providing feedback and guidance on design and development issues.

Stage 4: The participants will be made aware of the possible range of learning profiles that exist and their impact on the learning process through discussion, comparison and locating their own profile within the set of all possible profiles. This is an iterative, dynamic and ongoing process. In the context of this research project, this process will be facilitated by the provision of online discussion spaces to allow each participant to share his or her profiles and reflections with those at each of the institutions involved.

Stage 5: The online discussion spaces will be part of the project website which will also act as a regularly updated data resource. The resources will include the participant profiles, student profiles, example environments from previous studies, and links to other learning resource centres. Where possible, participants will be encouraged to focus on the adaptation and reuse current resources rather than the creation of completely new resources.

Stage 6: The participants will develop a series of teaching strategies - e.g. a general (meta) strategy, a strategy for the academic year, for each semester, for each unit - based on the above elements of the research process. Using these resources and their reflections on and understanding of their learning profiles, the participants will work through a series of planning exercises for a set of diversely profiled students groups (large, small, lecture, seminar, tutorial) with the purpose of working out a series of approaches which they would deem suitable for the dynamic interaction of themselves and the various student groups.

It is intended that these six stages will be completed during the initial program period. In each 
case, a small network approach to the dissemination of the techniques involved is used - project leader to institutional leaders, institutional leaders to institutional teams. This approach provides a flexible outlined plan which can be adapted according to subject area and organizational unit size. The reflective and participative design techniques (or other suitable active learning task) can then be used by each of the participants with their own students or passed on to colleagues via staff development workshops or less formal methods.

\section{Teaching Team and Student Learning Focus}

The methodology of profiling and related design work will then be integrated with the units taught by the participants, allowing student involvement. The process for the students will be essentially the same. The learning profile instruments will be administered at the start of the respective units, fed back to the students for reflection and integrated with one of the unit assignments. Again, pre- and post-attitudinal surveys and a range of other data collection instruments such as semi-structured interviews will be administered to both academics and students in order to help evaluate the process and project from both perspectives. The consideration of the process from both a teacher and student perspective provides several additional features that allow a comparative analysis of the program experience.

\section{Outcomes for Students}

For the students, the outcomes mirror those expanded upon above for the university teachers, but more specifically associated with learning. These include the following.

- Participation in the process will help students to develop metacognitive awareness and selfregulatory skills and to explore their attitudes to learning individually in groups and as a member of a wider learning community.

- Students will engage in a peer group discussion plus an individual reflective design project and produce a negotiated end product in the form of a personalised learning portal.
- A framework will be provided (by the learning profile and RAPAD) that will afford both a structure to work within and a process to follow.

Students engaged in the process will further understand learning and creative work in the context of a technology related project (again, this can be adapted for suitable projects for other subjects).

- As a product of the process, students will acquire a resource which will work in several ways and on several levels - a portal to a learning community, an information organizer, a learn-place, a virtual/physical interface and a cognitive interface

\section{Formative and summative evaluation}

Formative project evaluation will be undertaken to ensure the quality of the planning process, the consistency of the goals and the effectiveness of the project design. This will be achieved by undertaking an iterative review process using techniques such as external consultation, design review, expert review and one on one review.

Summative project evaluation of each of the main and additional outcomes will be undertaken to measure and evaluate the project outcomes and to provide information for future iterations. An important part of the evaluation at an individual level is provided by the use of a reflective and participative methodology (RAPAD) which provides structure, process and checkpoints for the participants. In addition, a series of pre- and post-project measures, designed to effectively evaluate the level of outcome attainment, will also be used for this purpose. Both quantitative and qualitative instruments will be employed.

\section{Conclusions}

This paper outlined a program of teaching for learning in the knowledge society by promoting conceptual change in academics' approaches to teaching. The mechanism for operationalising these matters is provided by the concept of student learning profiles. Each individual has a learning profile, 
the core constituents of each profile are cognitive style, learning style and personality type. These three profile components interact in ways which produce very individual and personalised approaches to learning. Facilitating an understanding of the range of possible learner profiles via accessing and reflecting on their own profile can help enable academics to become more effective teachers amidst the increasing demands of higher education as we move towards a more full-fledged knowledge society. A methodological approach, series of stages and suggested outcomes has been presented as a possible way of accomplishing this.

\section{References}

Argyris, C., \& Schön, D. A. (1996). Organizational Learning II. Reading, MA: Addison-Wesley Publishing Company.

DfES. (2004). A National Conversation about Personalised Learning. (DfES/09/9/2004). Nottingham: Department for Education and Skills.

Entwistle, N., Tait, H., \& McCune, V. (2000). Patterns of response to an approach to studying inventory across contrasting groups and contexts. European Journal of the Psychology of Education, 15, 33-48.

Entwistle, N. (2003). University Teaching-Learning Environments and Their Influences on Student Learning: An Introduction to the ETL Project, Proceedings of IOth Conference of the European Association for Research on Learning and Instruction (EARLI). Padova, Italy: EARLI.

Ison, R. (1999). Applying Systems Thinking to Higher Education. Systems Research and Behavioral Science, 16, 107 112.

Ison, R. L. (2000). Supported open learning and the emergence of learning communities. The case of the Open University UK. In R. Miller (Ed.), Creating Learning Communities. Models, Resources, and New Ways of Thinking about Teaching and Learning (pp. 90-96). Brandon VT: Solomon Press.

Jonassen, D. H., \& Grabowski, B. L. (1993). Handbook of Individual Differences, Learning, and Instruction. Hillsdale, NJ: Lawrence Erlbaum.
Laurillard, D. (1999). A Conversational Framework for Individual Learning Applied to the 'Learning Organisation' and the 'Learning Society'. Systems Research and Behavioral Science, $16,113-122$.

Lockee, B., Moore, M., \& Burton, J. (2002). Measuring Success: Evaluation Strategies for Distance Education. Educause Quarterly, 2002(I), 20-26.

Martinez, M. (200I). Key design considerations for personalized learning on the web. Educational Technology and Society, 4(I), 26-40.

Metros, S. E., \& Bennett, K. (2002). Learning Objects in Higher Education. Educause Research Bulletin, 2002(19), 2-10.

Ramsden, P. (1992). Learning to Teach in Higher Education. London: Routledge.

Riding, R. J. (1991). Cognitive Styles Analysis. Birmingham: Learning and Training Technology.

Riding, R. J. (200I). The Nature and Effects of Cognitive Style. In R. J. Sternberg \& L. F. Zhang (Eds.), Perspectives on Thinking, Learning and Cognitive Styles (pp. 47-72). Mahwah, NJ: Lawrence Erlbaum.

Peterson, E. R., Deary, I. J., \& Austin, E. J. (2003). The reliability of Riding's Cognitive Style Analysis test. Personality and Individual Differences, 34, 88I-89I.

Schön, D. (1983). The Reflective Practitioner. New York: Basic Books.

Schön, D. A. (199I). The Reflective Turn: Case Studies In and On Educational Practice. New York: Teachers Press: Columbia University.

Tait, H., Entwistle, N. J., \& McCune, V. (1998). ASSIST: a reconceptualisation of the Approaches to Studying Inventory. In C. Rust (Ed.), Improving Student Learning (pp. 262-27I). Oxford: Oxford Centre for Staff and Learning Development.

Webster, W. R. (2004). A Learner-Centred Methodology for Learning Environment Design and Development, Proceedings of Online Learning and Training 2004: Exploring Integrated Learning Environments, Brisbane, 2-3 November 2004. Brisbane: Queensland University of Technology.

Webster, W. R. (2005). A Reflective and Participative Approach to the Design of Personalised Learning Environments. PhD Thesis. Lancaster: Lancaster University. 


\section{About the Authors}

Ray Webster (r.webster@murdoch.edu.au)

Fay Sudweeks (sudweeks@murdoch.edu.au)

School of Information Technology

Murdoch University

Murdoch WA 6150, Australia 